a considerable proportion are minor typographical errors, unfortunately inevitable in papers consisting mostly of names and numbers. Most of the others are inserted to bring the "list" into line, as far as possible, with Reuter's work.**

Regarding Angerianus, Mr. Distant is in error; if he will refer to the 'Canadian Entomologist,' p. 374, he will see that I have deleted it from the list of unrecognized genera. Those who have had occasion to wrestle with Mr. Distant's genera will not wonder that I have slipped up occasionally.

I could write a good deal more on this subject, but desire to keep strictly to Mr. Distant's note. Those who are interested in the matter can refer to Reuter's paper ("Hemipterologische Spekulationen, I. Die Klassification der Capsiden," in 'Festschrift für Palmen,' no. 1, pp. 1-58 (dated 1905)).

\title{
DESCRIPTION OF A NEW SPECIES OF TINGIDID\# FROM HONOLULU.
}

\author{
By W. L. Distant.
}

I Recentur received four specimens of a Tingid from $\mathrm{Mr}$. Jacob Kotinsky, Assistant Entomologist to the Board of Commissioners of Agriculture and Forestry, Honolulu, with a request that I would identify the species. It had been determined by Mr. Kirkaldy as Teleonemia bifasciata, Champ., a species described from Central America; but from this it is quite distinct - by the markings of the elytra, the less prominently curved outer discal carinations of the pronotum, and the shorter apical joint to the antennæ. Under Champion's name it therefore appears in the Entomological Report for 1905 of the Territory of Hawaii. A figure is also given of the species, but in printing the same the dark fasciæ to the elytra have not been reproduced. Mr. Kotinsky states in the above-mentioned Report that it is an introduced insect, and that it " has inflicted terrible injury upon lantana."

The following is a description of this Tingid :-

\section{Teleonemia lantane, sp. n.}

Head, pronotum, antennæ, and body beneath dull fuscous; elytra brownish ochraceous, the discoidal area with two longitudinal piceous or black fasciæ, the innermost broadest and curved, the outermost more slender, straighter, and broken; sutural area with an undulating, oblique, central fascia, and an outer submarginal narrower and more broken fascia, piceous or black; femora fuscous, the tibiæ pale ochra-

* I have no doubt there are other errors of synonymy, \&c., yet to be adjusted, and will be obliged to my colleagues for advice of the same. 
ceous, with their apices and bases narrowly piceous, tarsi piceous; antennæ moderately stout, first and second joints about equal in length, fourth about as long as first and second united; pronotum prominently palely tricarinate, the lateral margins also carinate; of the three discal carinations, the outermost are only slightly curved, and a little inwardly turned towards base, the interspaces rugulose and finely punctate; elytra long, constricted behind the middle, rounded at apex; costal area with small, distinct, subhyaline, creamy-white areolets, their dividing lines fuscous; sutural area with an apical cluster of creamy-white areolets. Long. $3 \frac{1}{2}$ to 4 millim.

Hab. Honolulu, Oaku (J. Kotinsky).

\section{BIBLIOGRAPHICAL AND NOMENCLATORIAL NOTES ON THE RHYNCHOTA.}

By G. W. Kirkaldy.

IN the 'Entomologist' for December (p. 274), Mr. Distant comments upon certain hemipterous genera recently discussed nomenclatorially by me.

The review in 'Nature' of July 5th (lxxiv. p. 220) was the first intimation I received that the third volume of $\mathrm{Mr}$. Distant's work on Indian Hemiptera had been published. The sixth of my bibliographical notes (Entom. 1906, pp. 247-9) was sent away before that, and as, in the 'Entomologist' for January, 1906 (p. 8), Mr. Distant had proposed names for certain preoccupied genera (in the Fulgoroidea) erected by Melichar in 1903, I naturally concluded that the English author had overlooked the preoccupation of "Kirbya," about which I had, indeed, written to Melichar in 1904. As it was, I wrote to the Editor, hoping to cancel it, but was too late.' My synonymic note on Coanaco was also despatched before $\mathrm{Mr}$. Distant's correction was published. These matters are, of course, of trivial importance, and, indeed, inevitable where two or more workers are traversing parts of the same ground.

The discarding of Opinus (even if possible, which I do not admit) would not render Sminthocoris valid, as Tapeinus would still be available.

I was quite aware of the existence of Penthicodes, which is a strict synonym of Aphana. It was not founded for a special type, but expressly to replace the preoccupied Penthicus, which also was expressly erected to replace Aphena, which was supposed to be preoccupied by Aphanus. The types of Aphena, Penthicus, and Penthicodes are therefore one and the same, as indicated already. 


\section{$2 \mathrm{BHL}$ Biodiversity Heritage Library}

Distant, William Lucas. 1907. "Description of a new species of Tingidae from Honolulu." The Entomologist 40, 60-61. https://doi.org/10.5962/bhl.part.26481.

View This Item Online: https://www.biodiversitylibrary.org/item/42356

DOI: https://doi.org/10.5962/bhl.part.26481

Permalink: https://www.biodiversitylibrary.org/partpdf/26481

\section{Holding Institution}

Smithsonian Libraries

\section{Sponsored by}

Smithsonian

\section{Copyright \& Reuse}

Copyright Status: NOT_IN_COPYRIGHT

This document was created from content at the Biodiversity Heritage Library, the world's largest open access digital library for biodiversity literature and archives. Visit BHL at https://www.biodiversitylibrary.org. 